\title{
Hot Box Investigations of a Ventilated Bioclimatic Wall for NZEB Building Façade
}

\author{
Dwinanto Sukamto $\mathbb{D}^{\mathrm{D}}$, Monica Siroux *(D) and Francois Gloriant \\ INSA Strasbourg ICUBE, University of Strasbourg, 67000 Strasbourg, France; \\ dwinanto.sukamto@insa-strasbourg.fr (D.S.); francois.gloriant@insa-strasbourg.fr (F.G.) \\ * Correspondence: monica.siroux@insa-strasbourg.fr; Tel.: +33-3881-447-53
}

Citation: Sukamto, D.; Siroux, M.; Gloriant, F. Hot Box Investigations of a Ventilated Bioclimatic Wall for NZEB Building Façade. Energies 2021, 14, 1327. https://doi.org/10.3390/ en14051327

Academic Editor: Fabrizio Ascione

Received: 1 February 2021

Accepted: 23 February 2021

Published: 1 March 2021

Publisher's Note: MDPI stays neutral with regard to jurisdictional claims in published maps and institutional affiliations.

Copyright: (c) 2021 by the authors. Licensee MDPI, Basel, Switzerland. This article is an open access article distributed under the terms and conditions of the Creative Commons Attribution (CC BY) license (https:// creativecommons.org/licenses/by/ $4.0 /)$.

\begin{abstract}
The building sector is the largest consumer of energy, but there are still major scientific challenges in this field. The façade, being the interface between the exterior and interior space, plays a key role in the energy efficiency of a building. In this context, this paper focuses on a ventilated bioclimatic wall for nearly zero-energy buildings (NZEB). The aim of this study is to investigate an experimental setup based on a hot box for the characterization of the thermal performances of the ventilated wall. A specific ventilated prototype and an original thermal metrology are developed. This paper presents the ventilated prototype, the experimental setup, and the experimental results on the thermal performances of the ventilated wall. The influence of the air space thickness and the air flow rate on the thermal performances of the ventilated wall is studied.
\end{abstract}

Keywords: thermal performance; ventilated bioclimatic wall; air space thickness; air flow rate; hot box

\section{Introduction}

The building sector is the industry mainly responsible for energy consumption in Europe [1]. Reducing the energy consumption and the emission of gases from buildings has become a recent priority in Europe. In this context, France is placing the construction sector at the center of its strategy to meet this challenge [2]. Nowadays, buildings must ensure low energy consumption and comfortable environment quality. However, the building envelope has one of the largest impacts on building energy consumption. These aspects generate innovative façade design $[3,4]$. In particular, a ventilated façade can be also a response to this approach [5].

Ventilated façades are used often by architects. In addition to the aesthetic aspect, the primary purpose of this type of façade is to protect the insulation materials by dissipating moisture. A ventilated façade can also provide energy savings. Nowadays, in Europe, the construction of zero-energy buildings (ZEB) and the transformation of existing buildings into nearly zero-energy buildings (NZEB) are expected. For these reasons, a ventilated façade can be an interesting solution for both existing and new buildings.

A ventilated façade is composed of two panes separated by a ventilated cavity. One possible definition of ventilated façade is "A ventilated double facade can be defined as a traditional single façade doubled inside or outside by a second, essentially glazed facade. Each of these two facades is commonly called a skin. A ventilated cavity-having a width which can range from several centimetres at the narrowest to several metres for the widest accessible cavities-is located between these two skins" [6].

There are several different ventilated façade concepts and several classifications [5,6]. Generally, classifications are based on façade geometry, the type of ventilation of the cavity, and the airflow concept [7-9]. The ventilated façade can be continuous or divided into modules. The air layer forms a thermal buffer zone. The façade geometry can be box window type, shaft box type, a corridor façade, or a multi-story double skin façade. The cavity ventilation that occurs through openings in the external and internal skin can be 
natural, mechanical, or hybrid. Possible airflow concepts are as follows: supply air, exhaust air, static air buffer, external air curtain, and internal air curtain [10]. The presence of integrated systems (photovoltaic, solar collector) can also be classification criteria. For example, Ibanez-Puy [11] classifies ventilated façades as double skin façades, building integrated photovoltaic, solar chimneys, Trombe wall, solar wall, façade solar collectors, and opaque ventilated façades.

For several years, publications on ventilated walls increased significantly [12-15]. Despite the high number of publications on ventilated walls, the influence of the air space thickness cavity on the thermal performances of the ventilated wall was rarely studied. Table 1 provides an overview of different studies on the ventilated façade from the point of view of air space thickness.

Table 1. Overview of different studies on ventilated façades.

\begin{tabular}{clcc}
\hline Author & Years & Sample & Air Space Thickness \\
\hline A. Alaidroos [16] & 2016 & Ventilated wall & $0.1 \mathrm{~m}$ \\
O. Aleksandrowicz [17] & 2018 & Double skin façade & $0.2 \mathrm{~m}$ \\
J. Wang [18] & 2017 & Triple glazed windows & $0.03 \mathrm{~m}, 0.01 \mathrm{~m}$ \\
L. C. O. Souza [19] & 2018 & Ventilated double-skin façade & $0.1 \mathrm{~m}$ \\
J. Parra [20] & 2015 & Ventilated double-skin façade & $0.2 \mathrm{~m}, 2 \mathrm{~m}$ \\
G. Michaux [21] & 2019 & Triple glazed windows & $0.01 \mathrm{~m}$ \\
F. Gloriant [22] & 2021 & Triple glazed windows & $0.013 \mathrm{~m}$ \\
\hline
\end{tabular}

A hot box apparatus is used to measure the thermal behavior of large specimens of building materials. Two standard methods are given in the literature: guarded hot box (GHB) and calibrated hot box (CHB) $[23,24]$. The guarded hot box (GHB) is composed of three cells: a hot cell, a cold cell, and a guarded chamber used to minimize lateral heat losses. A calibrated hot box (CHB) is composed only of two cells: a hot cell and a cold cell [24]. Different standard hot box experiments can be carried out: the European EN ISO 8990, the American ASTM C1363-05, and the Russian GOST 26602.1-99 [23,24]. Many publications deal with the thermal characterization of building materials using a hot box apparatus. However, few papers studied the thermal properties of air cavity wall using a hot box. Aviram [25] studied the thermal behavior of a variable ratio cavity wall using a guarded hot box and CFD analysis. Lucchi [24] introduces a hot box procedure to study the thermal performance and the air flux in a wall with an internal air cavity. More recently, a new hot box was developed to study the hydrothermal behavior of historic walls [26].

This paper describes an experimental study on the thermal performance of a ventilated bioclimatic wall. The objective of this study was to develop an experimental setup able to characterize the influence of the air space thickness and the air flow rate on the thermal performances of the ventilated wall. A specific ventilated prototype and an original thermal metrology based on a hot box was developed in this study.

The overall structure of this paper takes the form of four parts, including this introduction. The second part, Experimental Setup, presents the ventilated bioclimatic prototype, the hot box, and the instrumentation involved in the test specimen. The third part presents the experimental results for ambient temperature, surface temperature, heat transfer coefficient, and pre-heating efficiency, which allows for the evaluation of the thermal performance of the ventilated wall. Finally, a conclusion gives a summary of the findings.

\section{Experimental Setup}

\subsection{Bioclimatic Ventilated Wall and Hot Box}

The ventilated wall prototype is presented in Figure 1. This prototype consists of two walls and a ventilated air chamber (a cavity between the two walls). The first wall is fixed, while the second one is mobile, allowing the thickness of the ventilated cavity to be varied. These two walls are made of an aluminum alloy and polyethylene. The dimensions are 
cold cell

$$
\begin{aligned}
& a=0^{\circ} \\
& a=75 \%
\end{aligned}
$$

$1 \mathrm{~m}$ high, $1 \mathrm{~m}$ wide, and $3 \mathrm{~mm}$ thick. Based on the manufacturer's data, the aluminum composite has a thermal resistance of $0.008 \mathrm{~m}^{2} \cdot \mathrm{K} \cdot \mathrm{W}^{-1}$ and has low roughness, with the surfaces being smooth. The ventilated air chamber is a non-hermetically sealed cavity that participates in the supply of fresh air to the building. A convective exchange takes place in the cavity along the axis of the wall, which disturbs the radial heat flow between the interior and exterior environments (Figure 1).

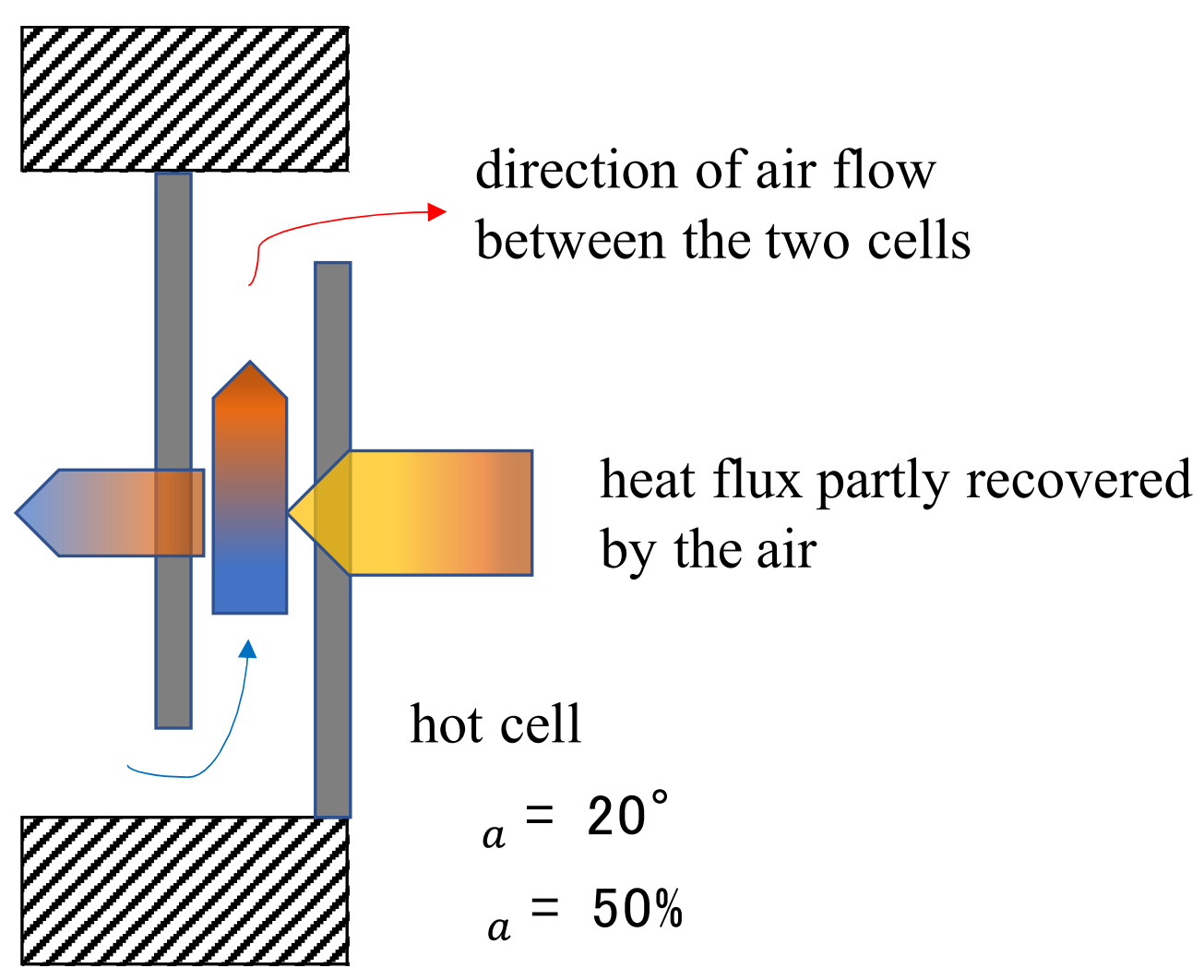

Figure 1. Ventilated wall.

The experimental study was carried out in a hot box (Figure 2). This hot box is a device composed of two climatic chambers whose ambiances are controlled. The first climatic chamber reproduced indoor conditions, and the second reproduced outdoor conditions (Figure 2). The hot box is characterized by a range of temperature from $-30{ }^{\circ} \mathrm{C}$ to $+60{ }^{\circ} \mathrm{C}$ and a range of humidity from $10 \%$ to $98 \%$. Each climatic chamber has its own refrigeration unit that allows for the production of cold with a temperature accuracy of $\pm 2{ }^{\circ} \mathrm{C}$. Each climatic chamber also has 3 electric resistors of $2.5 \mathrm{~kW}$ that allow for the production of heat with a temperature accuracy of $\pm 3{ }^{\circ} \mathrm{C}$. The hot box was connected to a computer to control the temperature and humidity of each climatic chamber. These two climatic chambers were separated by a sample holder (size of $1 \times 1 \times 0.4 \mathrm{~m}$ ). One of the two chambers was mounted on slides, allowing access to the sample holder as well as to the inside of the two climatic chambers. The ventilated bioclimatic prototype was fixed in the specimen holder. A ventilation system was used to impose air flow in the cavity. Moving the mobile wall can vary the air space thickness. 


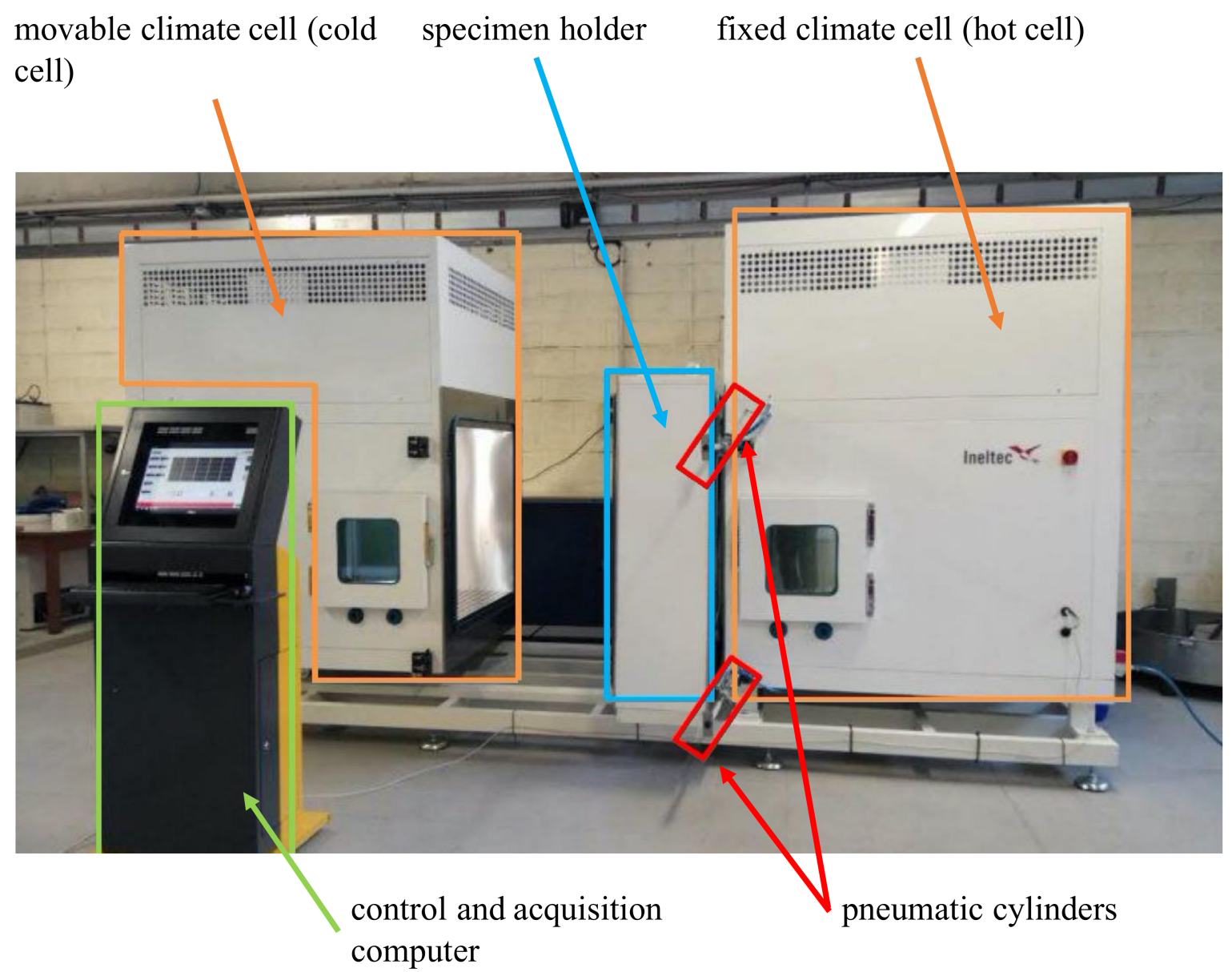

Figure 2. Hot box.

Experiments were carried out for different configurations to provide variable air space thickness and variable air flow rate. The air space thickness varied from $5 \mathrm{~mm}$ to $85 \mathrm{~mm}$. The air flow rate varied from 10 to $30 \mathrm{~m}^{3} \cdot \mathrm{h}^{-1}$. Fifty experiments were carried out. An overview of the fifty experiments is given in Table 2.

\subsection{Thermal Metrology}

The instrumentation was composed of K-type thermocouples and PT-100 probes. The hot box ambient temperature was measured in the hot cell and the cold cell with K-type thermocouples and PT-100 sensors (hot box sensors). The hot box instrumentation is presented in Figure 3. The ventilated prototype consisted of two walls and an air cavity. The first wall was fixed while the second one was mobile, allowing the thickness of the ventilated cavity to be varied. The wall surface temperature was measured by 24 K-type thermocouples (12 thermocouples on the fixed wall and 12 thermocouples on the mobile wall). The position of the thermocouples is given in Figures 4-6. Thermocouple measurements were compared to those obtained using an infrared camera (FLIR T650 SC). The infrared camera was installed in the front of the wall. The area covered by the infrared camera had a surface area of $10 \mathrm{~cm}^{2}$. The thermal flux was measured with 8 Captec flux meters ( 4 flux meters on the fixed wall and 4 flux meters on the mobile wall), allowing for the estimation of heat flux on both sides of the ventilated cavity (Figure 4). The air cavity temperature was measured by $10 \mathrm{~K}$-type thermocouples ( 4 thermocouples in the cavity, 3 thermocouples at the entrance of the cavity, and 3 thermocouples at the exit of the cavity). To control the airflow velocity inside the air cavity, a convergent plenum was installed (Figure 4). A fan was used to vary the airflow velocity inside the cavity. A CTV 210 hot wire anemometer from the manufacturer KIMO measured the airflow rate. All the 
sensors were connected to a Keithley 2700 data acquisition system. Data acquisition and processing were then carried out via the LabVIEW software (Figure 7).

Table 2. Overview of 50 experiments.

\begin{tabular}{|c|c|c|c|c|c|}
\hline Test Number & $\begin{array}{c}\text { Air Space Thickness } \\
(\mathrm{mm})\end{array}$ & $\begin{array}{l}\text { Air Flow Velocity } \\
\left(\mathrm{m}^{3} \cdot \mathrm{h}^{-3}\right)\end{array}$ & $\begin{array}{c}\text { Cold Cell } \\
\text { Temperature } T_{a 1} \\
\left({ }^{\circ} \mathrm{C}\right)\end{array}$ & $\begin{array}{c}\text { Hot Cell } \\
\text { Temperature } T_{a 2} \\
\left({ }^{\circ} \mathrm{C}\right)\end{array}$ & $\begin{array}{l}\text { Temperature Difference } \\
\text { between Hot Cell and } \\
\text { Cold Cell }\left({ }^{\circ} \mathrm{C}\right)\end{array}$ \\
\hline 1 & 5 & 9.94 & -4.34 & 15.56 & 19.9 \\
\hline 2 & 5 & 19.61 & -4.64 & 15.63 & 20.27 \\
\hline 3 & 5 & 29.99 & -4.45 & 15.82 & 20.27 \\
\hline 4 & 10 & 9.94 & -4.64 & 15.58 & 20.23 \\
\hline 5 & 10 & 19.96 & -4.72 & 15.61 & 20.32 \\
\hline 6 & 10 & 29.99 & -4.47 & 15.8 & 20.27 \\
\hline 7 & 15 & 10 & -4.61 & 15.58 & 20.19 \\
\hline 8 & 15 & 19.99 & -4.63 & 15.66 & 20.29 \\
\hline 9 & 15 & 30.09 & -4.41 & 15.87 & 20.28 \\
\hline 10 & 20 & 9.98 & -4.67 & 15.62 & 20.29 \\
\hline 11 & 20 & 20.43 & -4.66 & 15.64 & 20.29 \\
\hline 12 & 20 & 29.84 & -4.41 & 15.86 & 20.27 \\
\hline 13 & 25 & 10.02 & -4.67 & 15.61 & 20.28 \\
\hline 14 & 25 & 20.08 & -4.63 & 15.68 & 20.31 \\
\hline 15 & 25 & 29.81 & -4.43 & 15.87 & 20.3 \\
\hline 16 & 30 & 9.9 & -4.65 & 15.66 & 20.31 \\
\hline 17 & 30 & 19.85 & -4.62 & 15.71 & 20.33 \\
\hline 18 & 30 & 29.98 & -4.32 & 15.9 & 20.22 \\
\hline 19 & 35 & 10.22 & -4.65 & 15.63 & 20.28 \\
\hline 20 & 35 & 19.89 & -4.64 & 15.63 & 20.27 \\
\hline 21 & 35 & 30.039 & -4.32 & 15.95 & 20.28 \\
\hline 22 & 40 & 8.98 & -4.67 & 15.66 & 20.33 \\
\hline 23 & 40 & 20.07 & -4.61 & 15.74 & 20.35 \\
\hline 24 & 40 & 30.05 & -4.29 & 15.86 & 20.15 \\
\hline 25 & 45 & 9.04 & -4.66 & 15.64 & 20.3 \\
\hline 26 & 45 & 20.03 & -4.62 & 15.6 & 20.22 \\
\hline 27 & 45 & 30.07 & -4.40 & 15.91 & 20.31 \\
\hline 28 & 50 & 10.01 & -4.71 & 15.59 & 20.31 \\
\hline 29 & 50 & 20.04 & -4.65 & 15.62 & 20.27 \\
\hline 30 & 50 & 29.94 & -4.45 & 15.82 & 20.27 \\
\hline 31 & 55 & 9.99 & -4.62 & 15.66 & 20.28 \\
\hline 32 & 55 & 20.08 & -4.61 & 15.51 & 20.11 \\
\hline 33 & 55 & 30.01 & -4.37 & 15.77 & 20.14 \\
\hline 34 & 60 & 10.01 & -4.63 & 15.59 & 20.22 \\
\hline 35 & 60 & 19.73 & -4.58 & 15.7 & 20.28 \\
\hline 36 & 60 & 29.9 & -4.19 & 15.85 & 20.04 \\
\hline 37 & 65 & 10.01 & -4.65 & 15.52 & 20.17 \\
\hline 38 & 65 & 20.03 & -4.69 & 15.64 & 20.32 \\
\hline 39 & 65 & 30.05 & -4.45 & 15.85 & 20.3 \\
\hline 40 & 70 & 10.07 & -4.72 & 15.58 & 20.29 \\
\hline 41 & 70 & 20.03 & -4.64 & 15.53 & 20.16 \\
\hline 42 & 70 & 30.37 & -4.37 & 15.78 & 20.15 \\
\hline 43 & 75 & 9.98 & -4.68 & 15.47 & 20.15 \\
\hline 44 & 75 & 20.01 & -4.70 & 15.57 & 20.27 \\
\hline 45 & 75 & 30.62 & -4.38 & 15.71 & 20.09 \\
\hline 46 & 80 & 9.98 & -4.75 & 15.47 & 20.22 \\
\hline 47 & 80 & 20.49 & -4.66 & 15.59 & 20.25 \\
\hline 48 & 80 & 30.13 & -4.46 & 15.72 & 20.18 \\
\hline 49 & 85 & 9.99 & -4.67 & 15.49 & 20.16 \\
\hline 50 & 85 & 20.27 & -4.72 & 15.5 & 20.22 \\
\hline
\end{tabular}




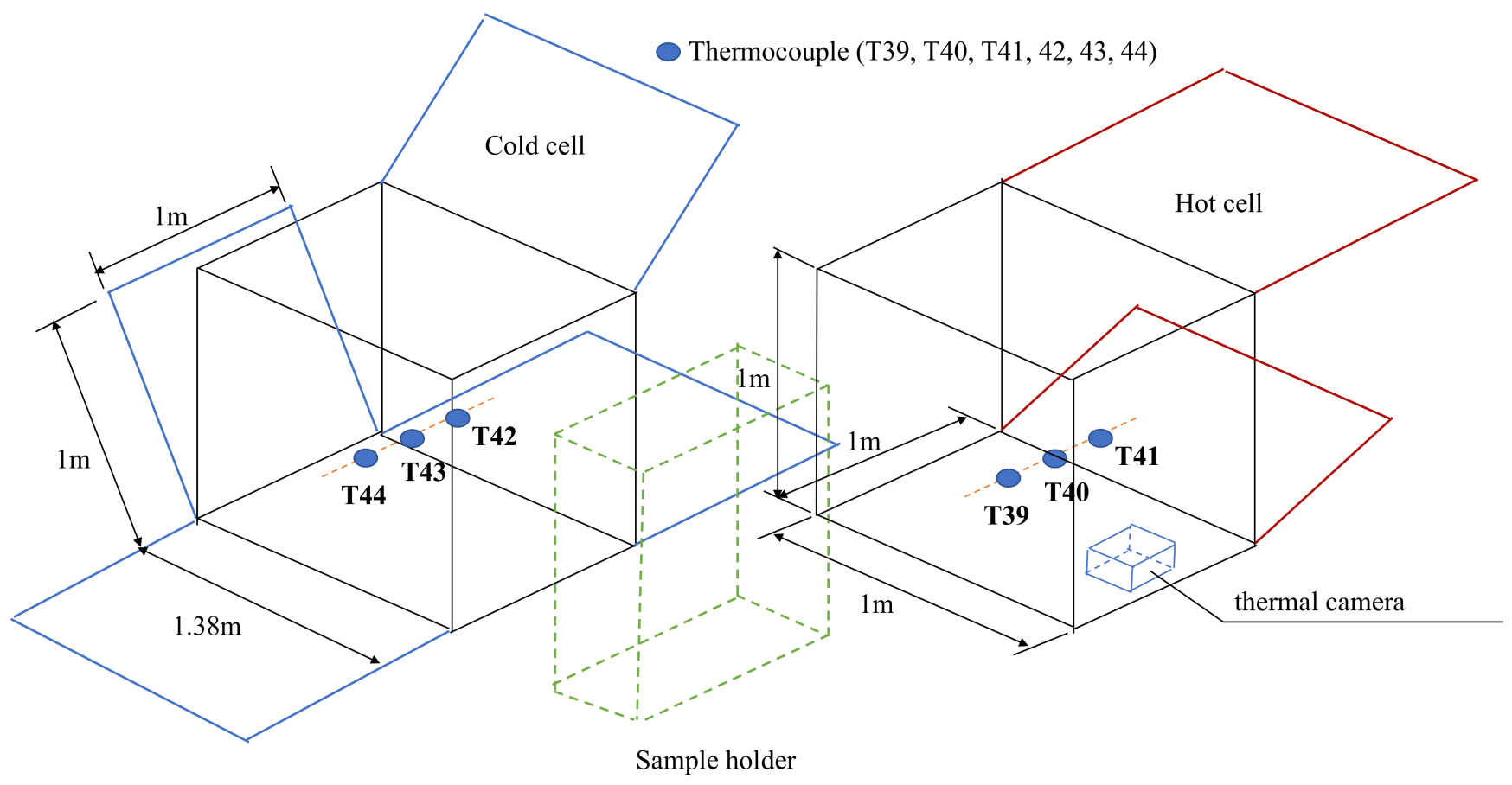

Figure 3. Hot box instrumentation. Two climatic chambers are separated by a sample holder. The ambient temperature is measured by 6 K-type thermocouples ( 3 thermocouples, T42, T43, and T44 in the cold cell and 3 thermocouples, T39, T40, T41 in the hot cell).

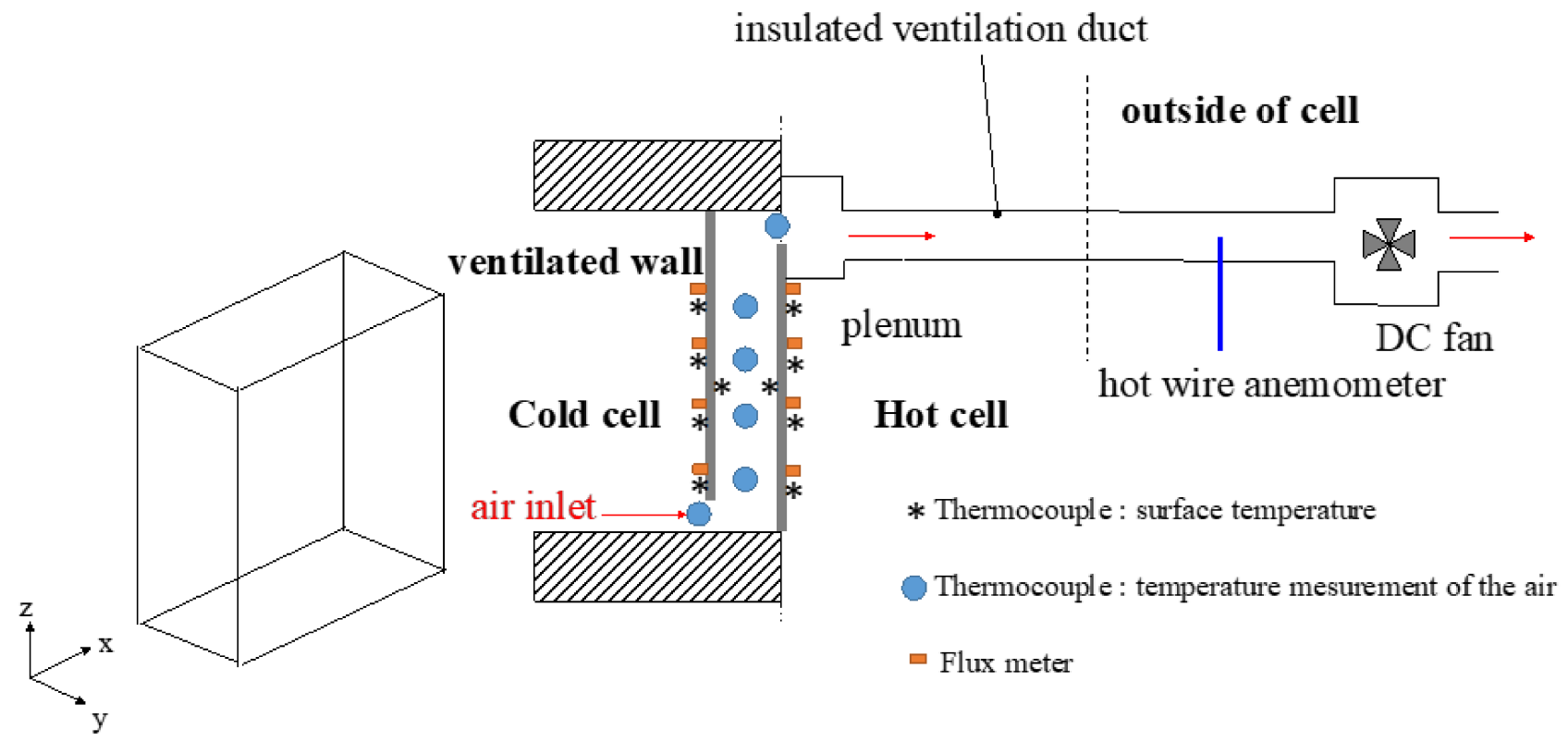

Figure 4. Ventilated wall instrumentation: wall surface temperature is measured by K-type thermocouples, air temperature is measured by K-type thermocouples, thermal flux is measured by flux meters, and airflow rate is measured by a hot wire anemometer. 

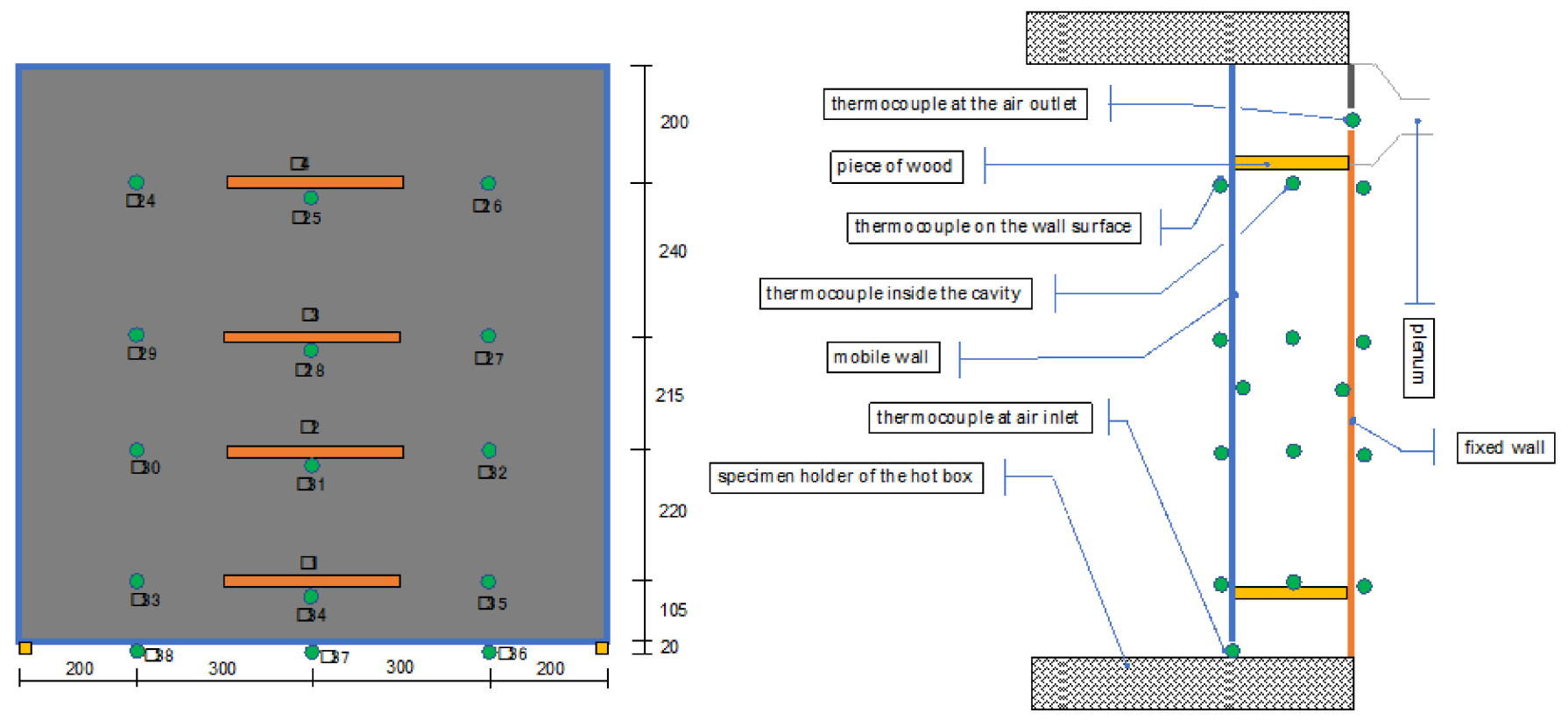

side view of the ventilated wall

Figure 5. Mobile wall instrumentation.

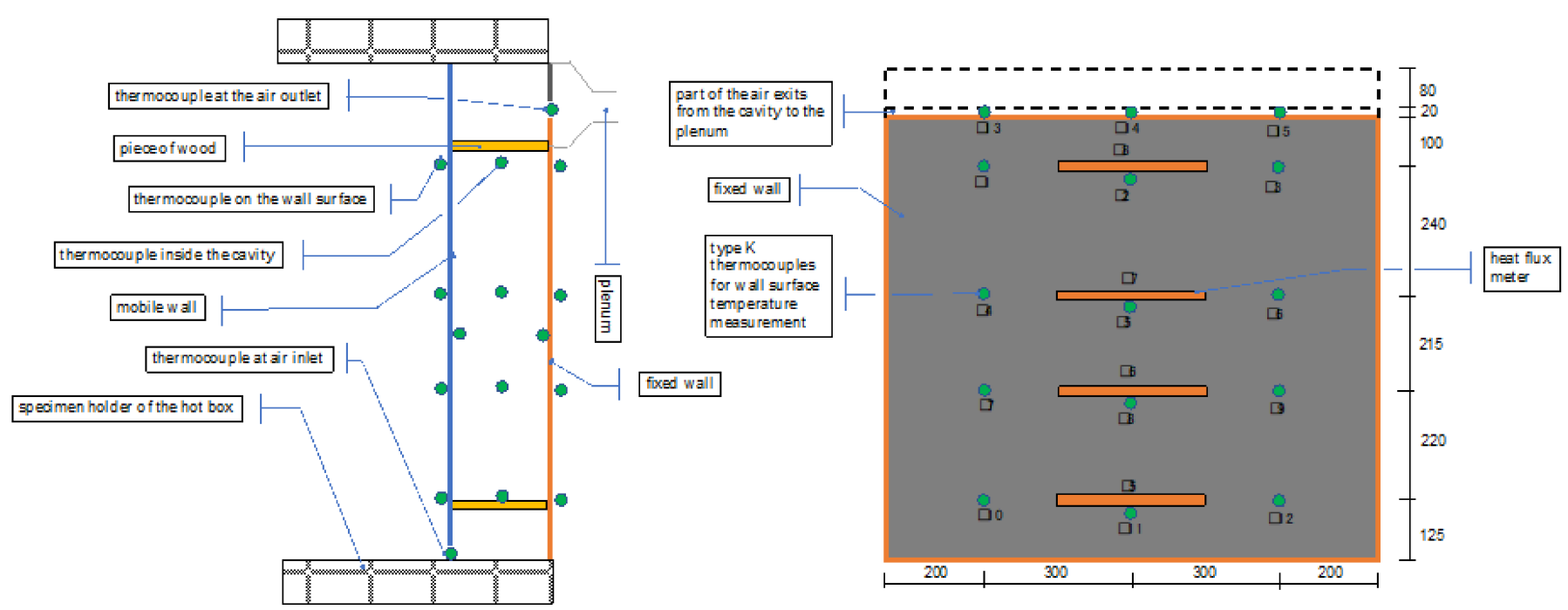

side view of the ventilated $w$ al

Figure 6. Fixed wall instrumentation. 


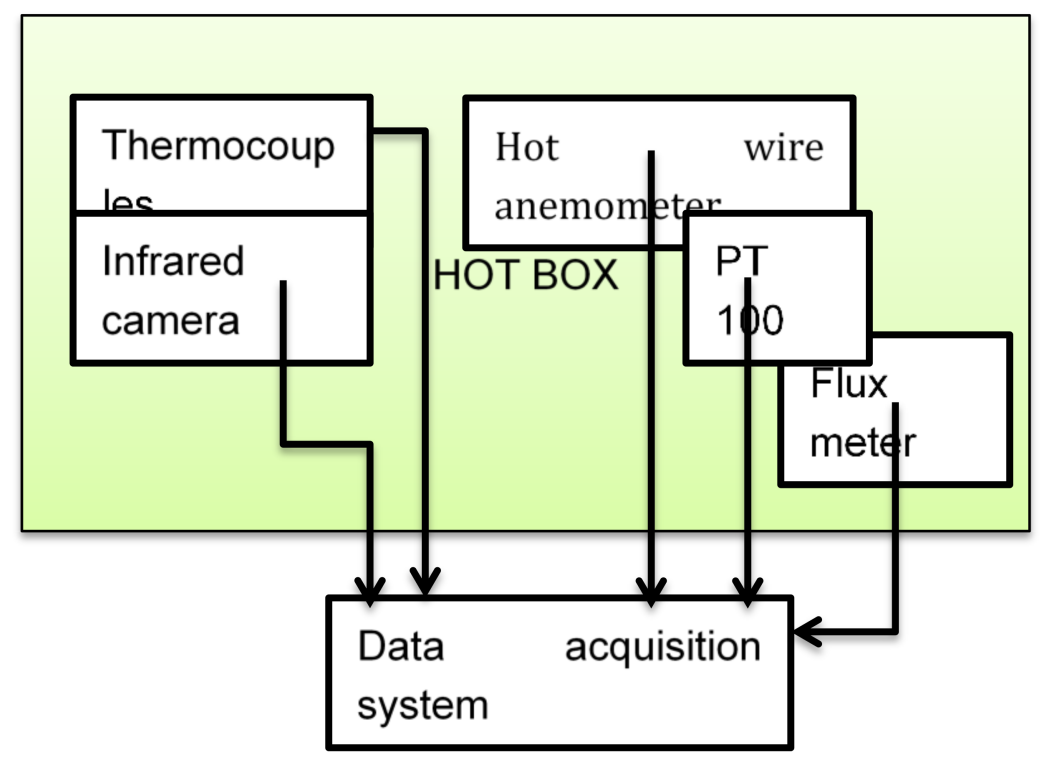

Figure 7. Data acquisition system.

The characteristics of the sensors used are given in Table 3.

Table 3. Thermal metrology.

\begin{tabular}{cccc}
\hline Type & Metrologic Means & Range & Uncertainty \\
\hline Air temperature & PT-100 & $-70{ }^{\circ} \mathrm{C}$ to $+200{ }^{\circ} \mathrm{C}$ & $0.1{ }^{\circ} \mathrm{C}$ \\
& K-type Thermocouples & $-75{ }^{\circ} \mathrm{C}$ to $+250{ }^{\circ} \mathrm{C}$ & $0.02{ }^{\circ} \mathrm{C}$ \\
Surface temperature & K-type Thermocouples & $-75{ }^{\circ} \mathrm{C}$ to $+250{ }^{\circ} \mathrm{C}$ & $0.02{ }^{\circ} \mathrm{C}$ \\
Thermal Flux & Infrared camera FLIR T650 SC & $-40{ }^{\circ} \mathrm{C}$ to $+150{ }^{\circ} \mathrm{C}$ & $1 \%$ \\
Captec Flux meter & & $5 \%$ \\
Air flow velocity & Hot wire anemometer KIMO & $0-30 \mathrm{~m} / \mathrm{s}$ & $0.3 \mathrm{~m} / \mathrm{s}$ \\
\hline
\end{tabular}

\section{Experimental Results}

Specific experiments were undertaken to test the hot box and the ventilated wall prototype (Figure 8). Experiments were carried out in steady state under the following conditions:

- Hot cell: ambient temperature conditions of $20^{\circ} \mathrm{C}$ and relative humidity (55\%);

- $\quad$ Cold cell: temperature conditions of $0{ }^{\circ} \mathrm{C}$ and relative humidity $(75 \%)$;

- Variable airflow rate: 10,20 , and $30 \mathrm{~m}^{3} \cdot \mathrm{h}^{-1}$;

- Variable air space thickness: from 5 to $85 \mathrm{~mm}$.

These specific experiments were carried out to investigate the ventilated wall prototype in terms of its capability to pre-heat the air in the cavity. Our experiments are distinguished from standard hot box methods used for the estimation of the thermal resistance of a wall in steady-state regime by using a calibrated hot box or guarded hot box such as EN ISO 8990.

\subsection{Ambient Temperature}

The ambient temperature was measured in both the hot cell and cold cell with K-type thermocouples and PT-100 sensors (hot box sensors). The temperature difference between the hot cell and the cold cell was $20^{\circ} \mathrm{C}$. This temperature difference allowed us to obtain a heat flux that could be measured correctly by the flux meters [27]. 


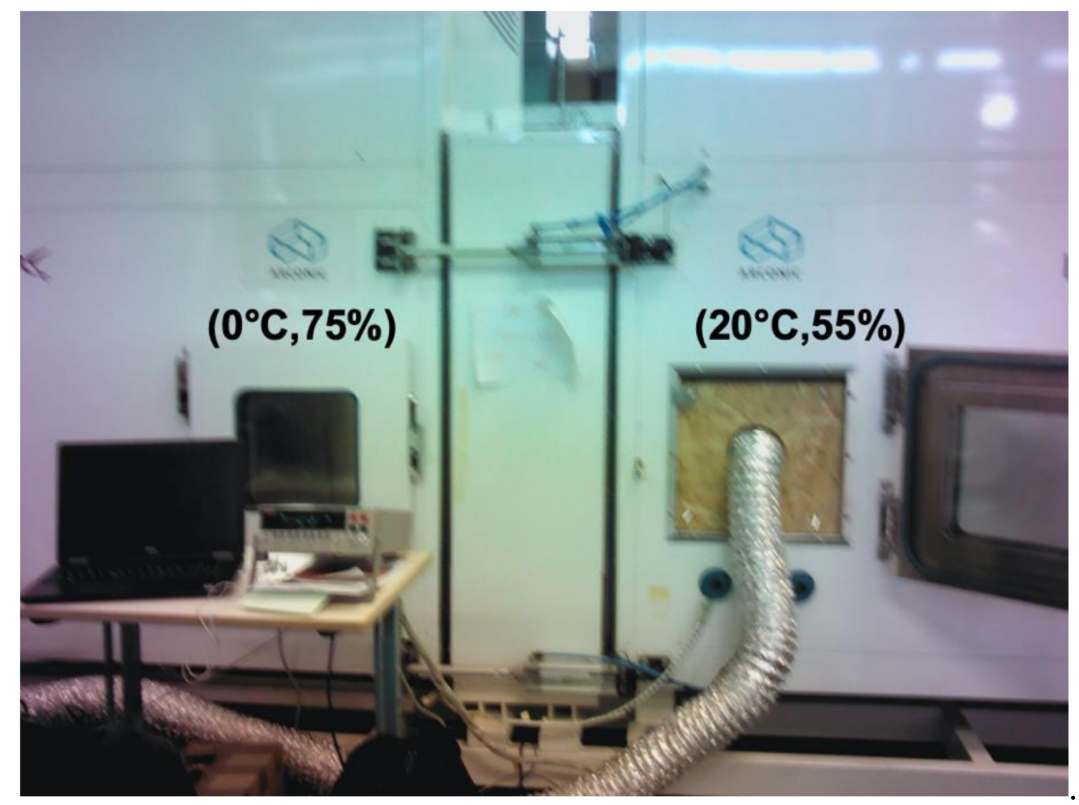

Figure 8. Experimental setup.

Under the specified conditions $\left(20^{\circ} \mathrm{C}\right.$ in the hot cell and $0{ }^{\circ} \mathrm{C}$ in the cold cell), a significant difference $\left(2.6^{\circ} \mathrm{C}\right.$ for the cold cell and $4.3^{\circ} \mathrm{C}$ for the hot cell) was observed between the ambient temperature measured with the hot box sensor and the ambient temperature measured by our thermocouples. This difference can be explained by the fact that the cells are not watertight, since an artificial air flow was created between them. However, for standard use of the hot box, there should not be any air exchange between the cells; the regulation system of the device was thus disturbed.

Figure 9 presents the air temperature in the cold cell and the hot cell. The temperature was measured by six K-type thermocouples (three thermocouples (T42, T43, and T44) in the cold cell and three thermocouples (T39, T40, and T41) in the hot cell). It can be seen in Figure 9 that the air temperature inside the hot box was homogenous in both the cold cell and the hot cell. The mean air temperature was $-4.6 \pm 0.05^{\circ} \mathrm{C}$ for the cold cell and $15.7 \pm 0.18^{\circ} \mathrm{C}$ for the hot cell.

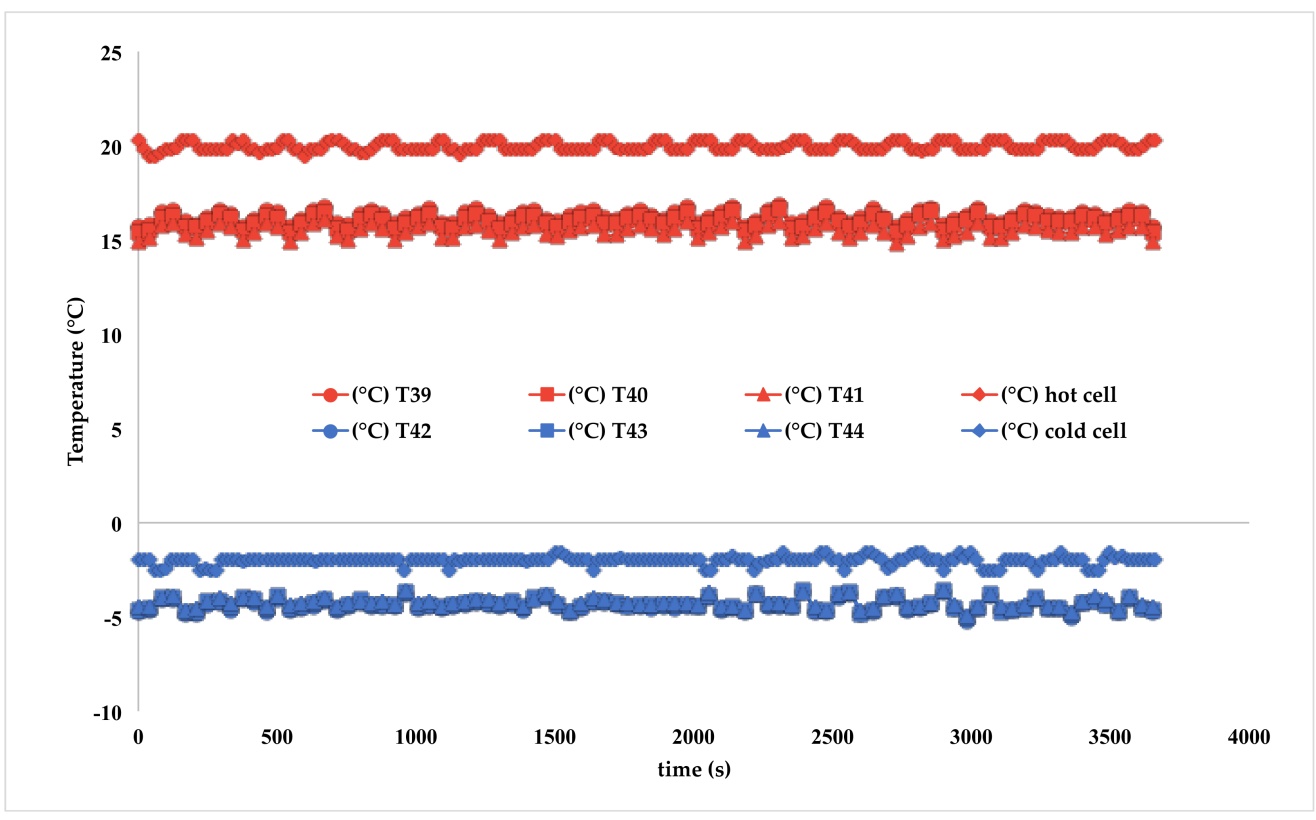

Figure 9. Ambient temperature in the cold cell and in the hot cell. 


\subsection{Surface Temperatures}

Measurement of surface temperatures was performed by thermocouples. Thermocouple measurements ( $\mathrm{T} 8$ and $\mathrm{T} 5$ thermocouple measurements) were compared to data obtained using an FLIR 650 TS infrared camera (Figure 10). The area covered by the infrared camera had a surface area of $10 \mathrm{~cm}^{2}$. The T8 and T5 thermocouples were located on the upper and lower part of this surface. The mean value measured by thermocouples T5 and T8 and the infrared camera were $12.14{ }^{\circ} \mathrm{C}, 12.11^{\circ} \mathrm{C}$, and $12.18^{\circ} \mathrm{C}$, respectively. The measurements of the surface temperature performed by the thermocouples are in accordance with the measurements made by the infrared camera and confirm the reliability of the instrumentation of the walls (Figure 11).

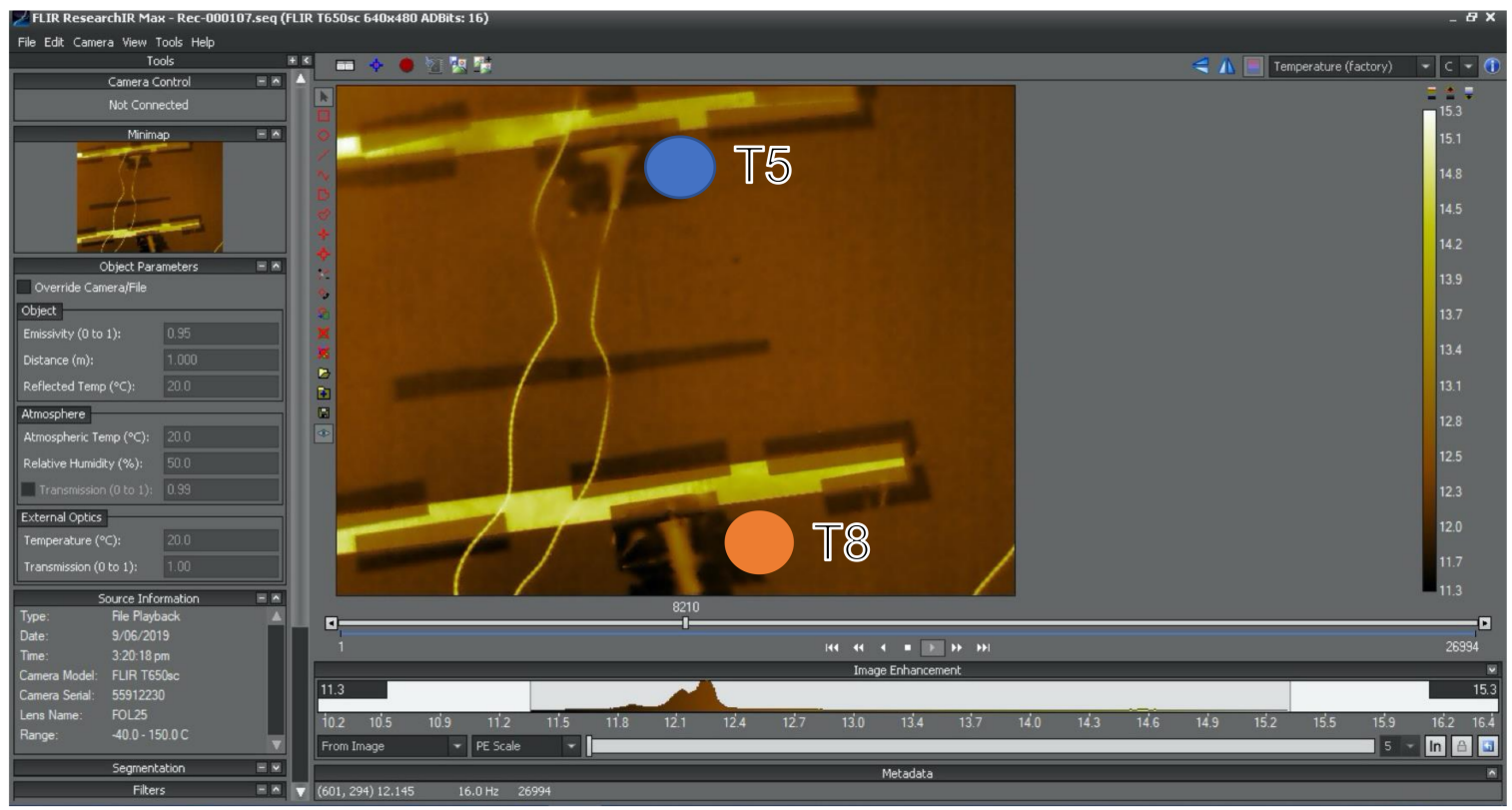

Figure 10. Surface temperature measurement by infrared camera.

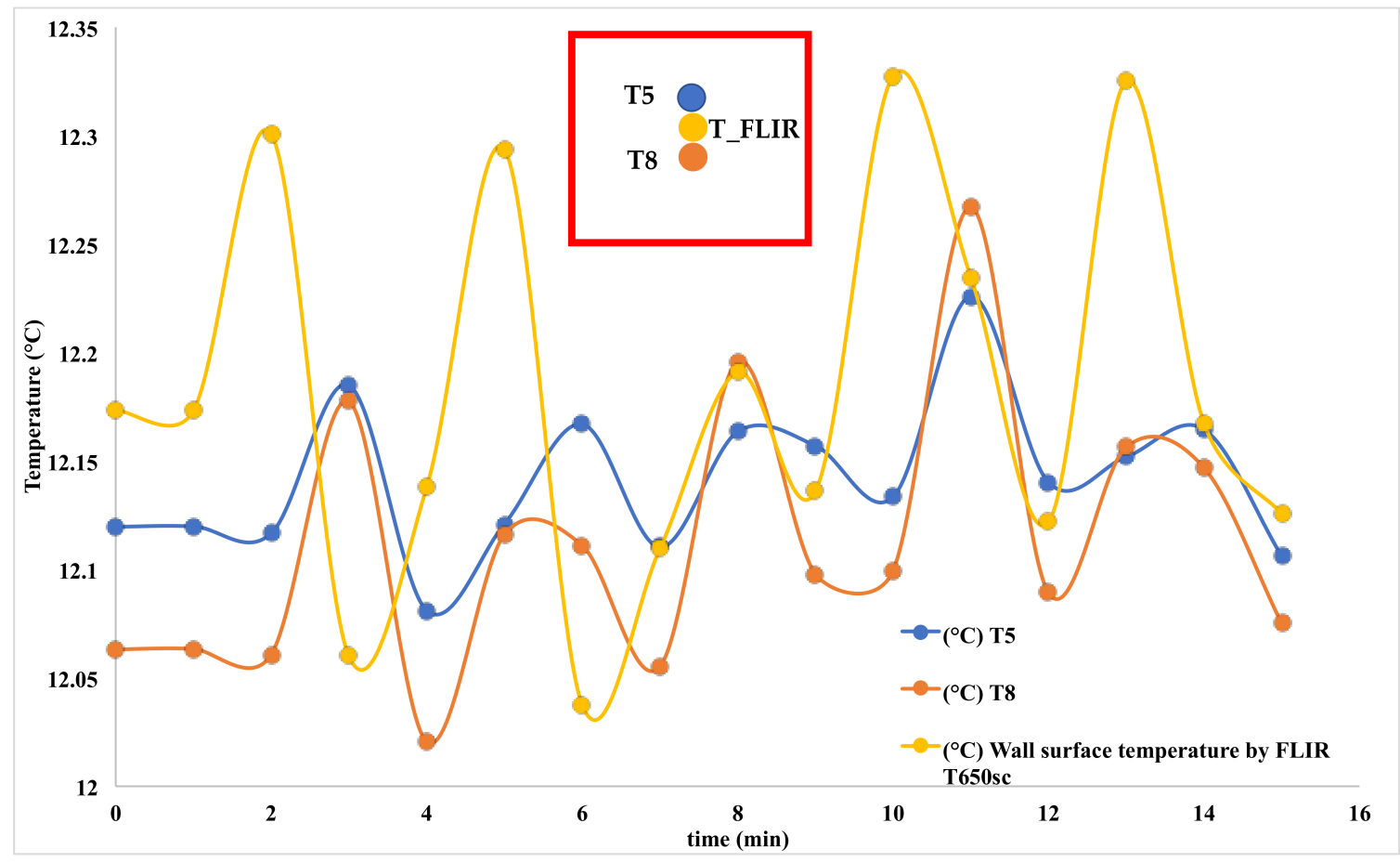

Figure 11. Surface temperature. Thermocouple and infrared camera measurements. 


\subsection{The Convection Heat Transfer Coefficient}

The convection heat transfer coefficient was estimated from Newton's law, involving the heat flux, the ambient temperature, and the wall temperature:

$$
h=q /\left(T_{s}-T_{a}\right)
$$

The heat flux, the ambient temperature, and the wall temperature were measured using thermal metrology describes before. We used two cavity thicknesses $(0.005$ and $0.01 \mathrm{~m}$ ) and three airflow rates $\left(10,20\right.$, and $\left.30 \mathrm{~m}^{3} \cdot \mathrm{h}^{-1}\right)$. Each sample wall was equipped with four flux meters and four thermocouples at different heights, making it possible to obtain four local estimates of the $h$-factor per cell. For the ambient temperature in each of the cells, a single air temperature was considered, corresponding to the average of the measurements of the three thermocouples installed in each cell. Figures 12 and 13 show the local convection heat transfer coefficient $h$ in the cold cell and in the hot cell. The values of the heat transfer coefficient varied between 15 and $25 \mathrm{~W} \cdot \mathrm{m}^{-2} \cdot \mathrm{K}^{-1}$. The mean value of the heat transfer coefficient was $19.9 \pm 1.3 \mathrm{~W} \cdot \mathrm{m}^{-2} \cdot \mathrm{K}^{-1}$ for the cold cell and $18.7 \pm 2.3 \mathrm{~W} \cdot \mathrm{m}^{-2} \cdot \mathrm{K}^{-1}$ for the hot cell. This order of magnitude is consistent with the correlations that can be found in the literature [28].

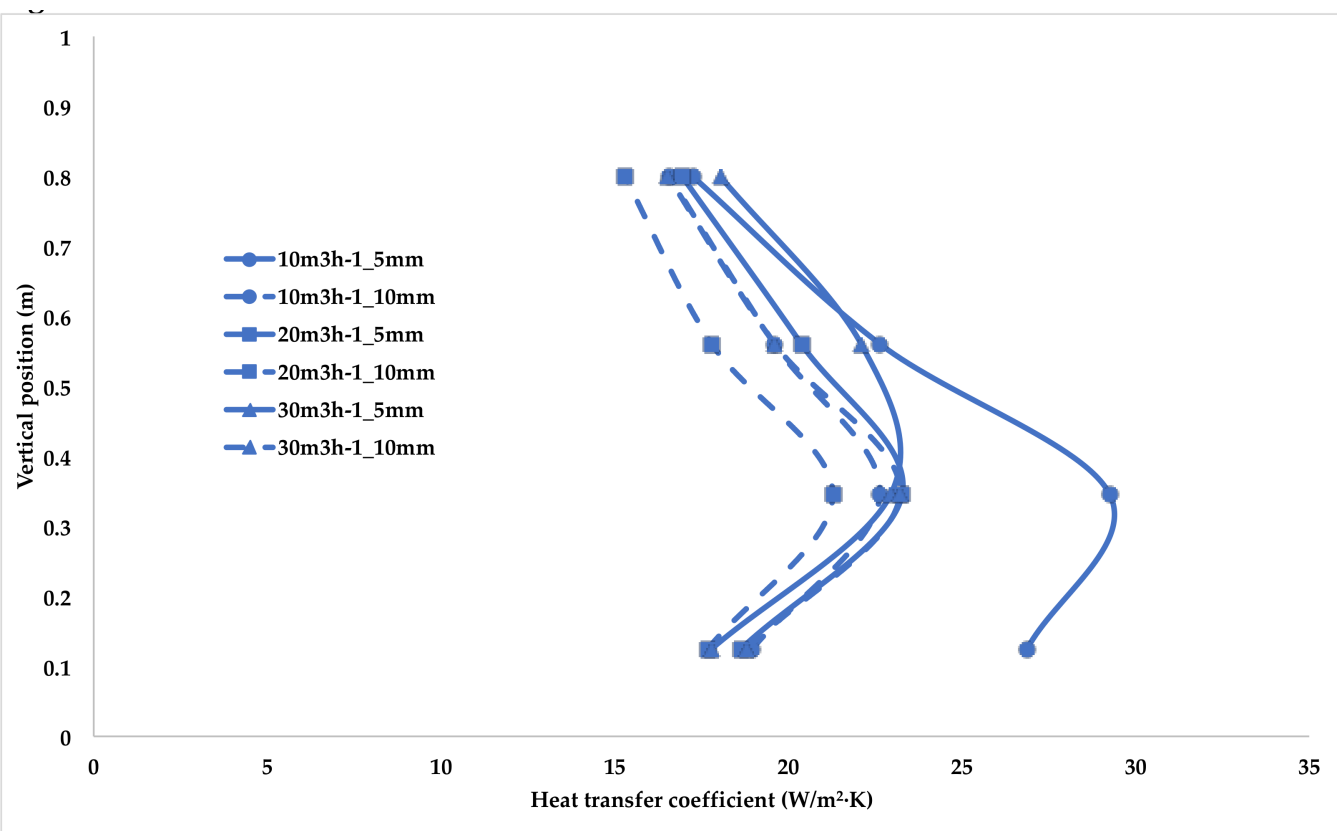

Figure 12. Local convection heat transfer coefficient in the cold cell.

From Figures 12 and 13, we also noted that the thickness of the cavity and the airflow rate had no significant influence on the convection heat transfer coefficient value. This means that these two parameters had no influence on the ambiances of the two climate cells. On the other hand, the coefficient $h$ depends on the position from which it was calculated, and it can be seen that for a given height, the estimates of the coefficient $h$ are relatively homogeneous. It can be thought that, in each of the cells, the air movements caused by the regulation system were not uniform near the walls of the sample, causing local variations in the coefficient $h$. As depicted in Figure 12, two values are apart for $10 \mathrm{~m}^{3} / \mathrm{h} \_5 \mathrm{~mm}$. This can be explained by a bad contact between the flux meters and the sample during this test. 


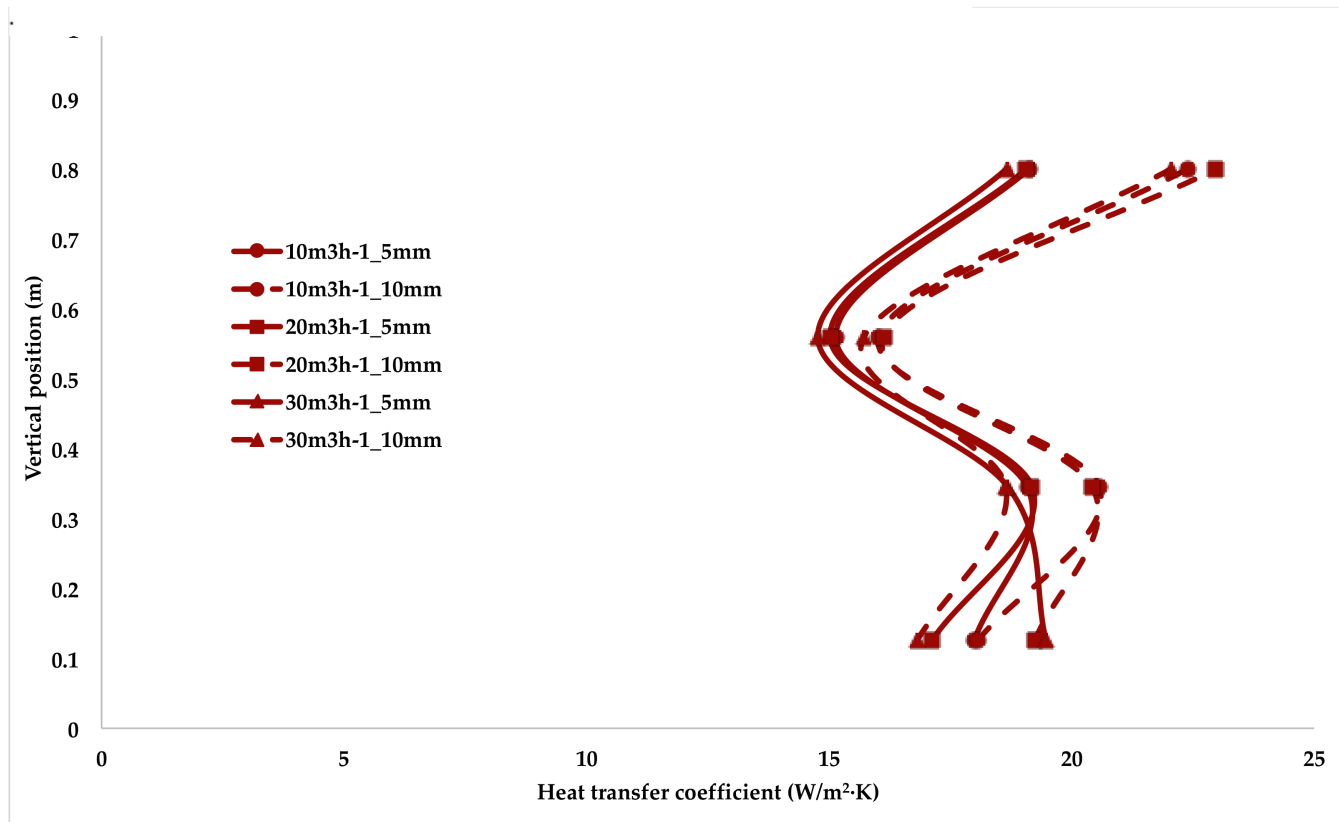

Figure 13. Local convection heat transfer coefficient in the hot cell.

Figures 14 and 15 show the global heat transfer coefficient in both the hot cell and the cold cell. The global heat transfer coefficient was estimated from temperature measurements (thermocouples) and heat fluxes (flux meters measurements). As we can see in Figures 14 and 15, there are small differences between the measurements, which can be explained by the uncertainties of the convection heat transfer coefficient.

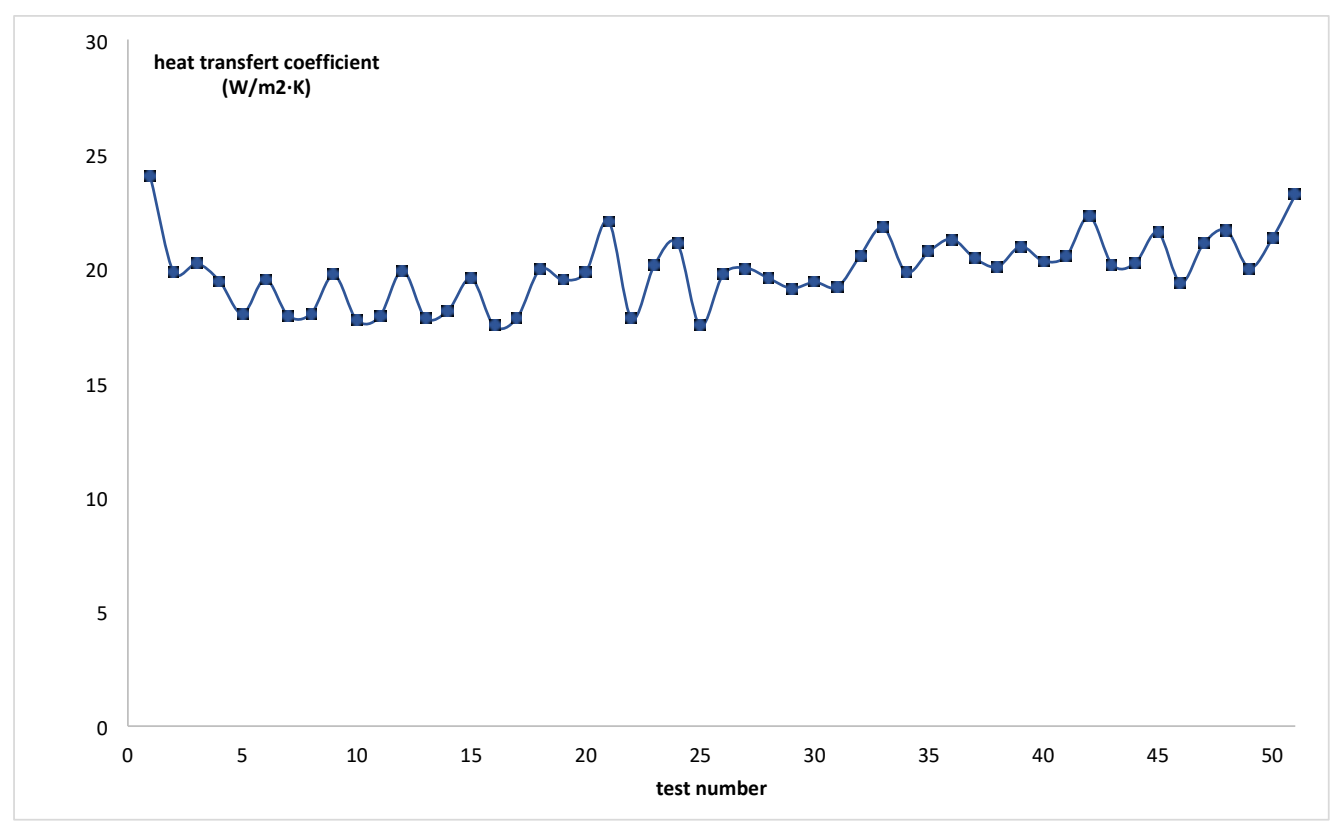

Figure 14. Global heat transfer coefficient (cold cell). 


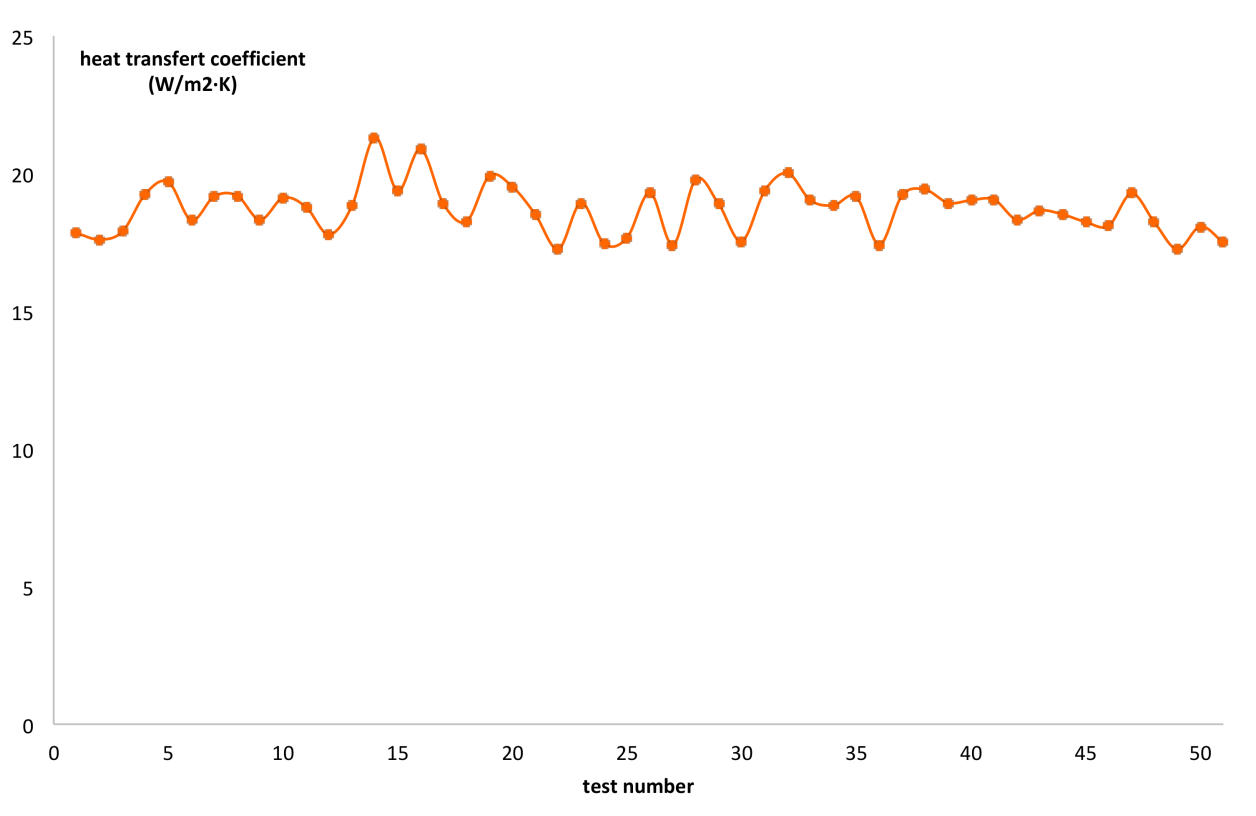

Figure 15. Global heat transfer coefficient (hot cell).

Finally, the uncertainties for the local convection heat transfer coefficient $h$ were estimated (Table 4). An uncertainty of $5 \%$ for the flux meters and an uncertainty of $0.02{ }^{\circ} \mathrm{C}$ for the thermocouples were considered. As can be observed from Table 4, the uncertainties are smaller in the hot cell, as the fluxes and temperature differences involved are larger. It is in the cold cell, at the lower part of the wall, that the uncertainties are the greatest; at this point, the temperatures between the wall and the environment of the cold cell are very close, often of the order of one-tenth of a degree.

Table 4. Uncertainties for the local convection heat transfer coefficient.

\begin{tabular}{|c|c|c|c|c|c|c|c|c|c|c|c|c|}
\hline \multirow[t]{3}{*}{ Vertical Position (m) } & \multicolumn{6}{|c|}{ Cold Cell } & \multicolumn{6}{|c|}{ Hot Cell } \\
\hline & \multicolumn{3}{|c|}{$\begin{array}{l}\text { Cavity of } 5 \mathrm{~mm} \text { for } 10,20, \\
30 \text { Flow Rate }\left(\mathrm{m}^{3} \cdot \mathrm{h}^{-1}\right)\end{array}$} & \multicolumn{3}{|c|}{$\begin{array}{l}\text { Cavity of } 10 \mathrm{~mm} \text { for } 10,20, \\
30 \text { Flow Rate }\left(\mathrm{m}^{3} \cdot \mathrm{h}^{-1}\right)\end{array}$} & \multicolumn{3}{|c|}{$\begin{array}{l}\text { Cavity of } 5 \mathrm{~mm} \text { for } 10,20, \\
30 \text { Flow Rate }\left(\mathrm{m}^{3} \cdot \mathrm{h}^{-1}\right)\end{array}$} & \multicolumn{3}{|c|}{$\begin{array}{l}\text { Cavity of } 10 \mathrm{~mm} \text { for } 10,20 \\
30 \text { Flow Rate }\left(\mathrm{m}^{3} \cdot \mathrm{h}^{-1}\right)\end{array}$} \\
\hline & 10 & 20 & 30 & 10 & 20 & 30 & 10 & 20 & 30 & 10 & 20 & 30 \\
\hline 0.8 & 1.5 & 1.5 & 1.7 & 1.5 & 1.4 & 1.7 & 1.5 & 1.5 & 1.4 & 1.8 & 1.8 & 1.6 \\
\hline 0.56 & 2.7 & 2.3 & 2.7 & 2.2 & 2.0 & 2.4 & 1.2 & 1.2 & 1.1 & 1.3 & 1.3 & 1.2 \\
\hline 0.35 & 4.6 & 3.0 & 3.0 & 3.1 & 2.7 & 3.2 & 1.5 & 1.6 & 1.5 & 1.6 & 1.6 & 1.4 \\
\hline 0.12 & 5.1 & 2.8 & 2.7 & 3.1 & 2.9 & 3.4 & 1.4 & 1.3 & 1.5 & 1.4 & 1.5 & 1.2 \\
\hline
\end{tabular}

\subsection{Thermal Performance of the Ventilated Wall}

The objective of this study was to characterize the influence of the air space thickness and the air flow rate on the thermal performances of the ventilated wall. The thermal performance of the ventilated wall was evaluated through the pre-heating efficiency according to Equation (2) "which represent the potentiality of the ventilatd wall in terms of its capability to pre-heat the air in the cavity" [29].

$$
E=\left(T_{\text {inlet }}-T_{\text {out }}\right) /\left(T_{\text {in }}-T_{\text {out }}\right)
$$

where

- $\quad T_{\text {inlet }}$ : the supply air temperature measured in the top of the air cavity;

- $\quad T_{\text {out }}$ : the outside air temperature (cold cell);

- $\quad T_{\text {in }}$ : the inside air temperature (hot cell). 
Figure 16 shows the pre-heating efficiency of the ventilated wall. Experiments were carried out for different air space thicknesses $(5,20,50$, and $85 \mathrm{~mm})$ and different air flow rates $\left(10,20\right.$, and $\left.30 \mathrm{~m}^{3} \cdot \mathrm{h}^{-1}\right)$. It can be seen that the pre-heating efficiency of the ventilated wall increased with the air space thickness. For an air flow of $10 \mathrm{~m}^{3} \cdot \mathrm{h}^{-1}$, the pre-heating efficiency of the ventilated wall increased from $57 \%$ (for an air space thickness of $5 \mathrm{~mm}$ ) to $65 \%$ (for an air space thickness of $85 \mathrm{~mm}$ ). It can be also seen that the pre-heating efficiency of the ventilated wall decreased with the air flow rate. For an air space thickness of $85 \mathrm{~mm}$, the pre-heating efficiency of the ventilated wall decreased from $65 \%$ (for an air flow rate $10 \mathrm{~m}^{3} \cdot \mathrm{h}^{-1}$ ) to $54 \%$ (for an air flow rate $30 \mathrm{~m}^{3} \cdot \mathrm{h}^{-1}$ ).

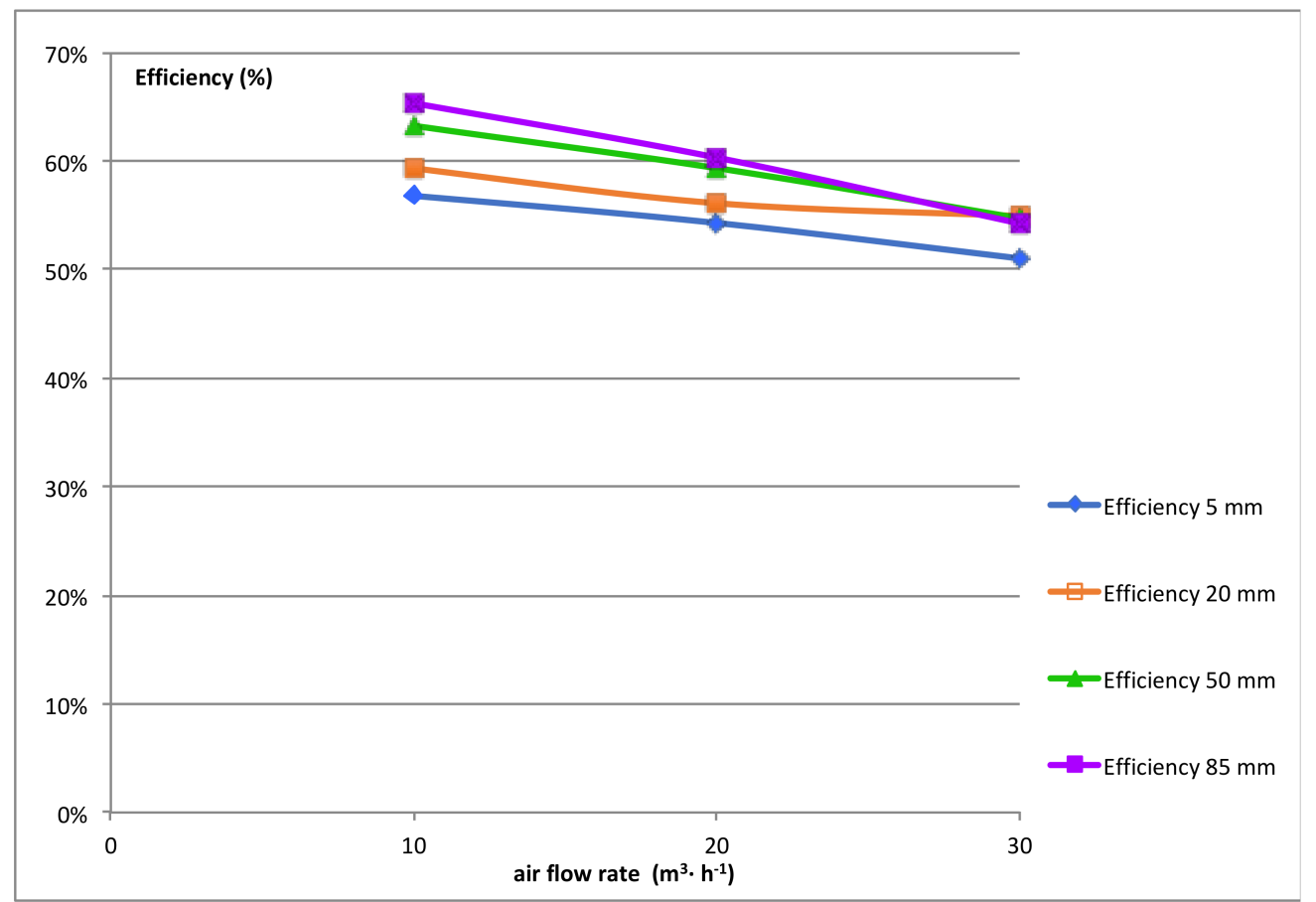

Figure 16. Pre-heating efficiency of the ventilated wall. Experiments were carried out for variable air space thicknesses $(5,20,50$, and $85 \mathrm{~mm})$ and variable air flow rates $\left(10,20\right.$, and $\left.30 \mathrm{~m}^{3} \cdot \mathrm{h}^{-1}\right)$.

\section{Conclusions}

This work describes an experimental study on the thermal performance of a ventilated bioclimatic wall. A ventilated wall prototype and an original hot box thermal metrology were developed. This paper presents the ventilated wall prototype, the experimental setup, and the experimental results. The ambient temperature, the surface temperature of the ventilated prototype, and the local heat transfer coefficients of the ventilated wall were measured. In addition, an uncertainty analysis on the local heat transfer coefficient is presented. Experimental results show that vertical position had a significant influence on the local heat transfer coefficient value. Finally, the influence of the air space thickness and the air flow rate on the thermal performances of the ventilated wall was studied. The results show the pre-heating efficiency of the ventilated wall increased with the air space thickness and decreased with the air flow rate. It is suggested that the increase in air space thickness of the ventilated wall can be used to obtain an interesting ventilated façade performance.

Author Contributions: Conceptualization, D.S. and M.S.; methodology, D.S., M.S. and F.G.; investigation D.S., M.S. and F.G. writing — original draft preparation D.S., M.S. and F.G., writing-review and editing D.S., M.S. and F.G. All authors have read and agreed to the published version of the manuscript.

Funding: This research was funded by Arconic Foundation and by the Ministry of higher education of Republic of Indonesia. 
Institutional Review Board Statement: Not Applicable.

Informed Consent Statement: Not Applicable.

Data Availability Statement: The data presented in this study are available on request from the corresponding author.

Acknowledgments: The authors acknowledge the financial contribution of the Arconic Foundation and the Ministry of higher education of Republic of Indonesia.

Conflicts of Interest: The authors declare no conflict of interest.

\section{Nomenclature}

$E \quad$ pre-heating efficiency of the ventilated wall

$h \quad$ convection heat transfer coefficient, W.m ${ }^{-2} \cdot{ }^{\circ} \mathrm{C}^{-1}$

$H R$ relative humidity inside the cell, $\%$

$T$ temperature, ${ }^{\circ} \mathrm{C}$

$q \quad$ flux density, $\mathrm{W} \cdot \mathrm{m}^{-2}$

\section{Indices}

a ambiance of the cell

in relative to the inside air temperature (hot cell)

inlet relative to the supply air temperature measured in the top of the air cavity

out relative to the outside air temperature (cold cell)

$s \quad$ wall surface

\section{References}

1. Bâtiments à Énergie Positive et Réduction Carbone. Available online: https:/ / www.batiment-energiecarbone.fr (accessed on 2 September 2020).

2. Evaluation of the Energy Performance of Building Directive 2010/31/EU. 2015. Available online: https://ec.europa.eu/ smart-regulation/roadmaps/docs/2016_ener_023_evaluation_energy_performance_ofbuildings_directive_en.pdf (accessed on 1 June 2015).

3. Pflug, T.; Nestle, N.; Kuhn, T.; Siroux, M.; Maurer, C. Modeling of facade elements with switchable U-value. Energy Build. 2018, 164, 1-13. [CrossRef]

4. Pflug, T.; Bueno, B.; Siroux, M.; Kuhn, T. Potential analysis of a new removable insulation system. Energy Build. 2017, 154, 391-403. [CrossRef]

5. Gregório-Atem, C.; Aparicio-Fernández, C.; Coch, H.; Vivancos, J.L. Opaque Ventilated Façade (OVF) Thermal Performance Simulation for Office Buildings in Brazil. Sustainability 2020, 12, 7635. [CrossRef]

6. Loncour, X.; Deneyer, A.; Blasco, M.; Flamant, G.; Wouters, P. Classification \& illustration of facade concepts. Contributed Report 03, Belgian Building Research Institute-BBRI. 2005. Available online: https:/ / www.aivc.org/resource/cr-03-ventilated-doubleskin-fa-ades-classification-illustration-facade-concepts (accessed on 1 June 2005).

7. Chan, H.Y.; Riffat, S.B.; Zhu, J. Review of passive solar heating and cooling technologies. Renew. Sustain. Energy Rev. 2010, 14, 781-789. [CrossRef]

8. Lai, C.M.; Hokoi, S. Solar façades: A review. Build. Environ. 2015, 91, 152-165. [CrossRef]

9. Barbosa, S.; Ip, K. Perspectives of double skin façades for naturally ventilated buildings: A review. Renew. Sustain. Energy Rev. 2014, 40, 1019-1029. [CrossRef]

10. Haase, M.; Marques da Silva, F.; Amato, F. Simulation of ventilated facades in hot and humide climate. Energy Build. 2009, 41, 361-373. [CrossRef]

11. Ibanez-Puy, M.; Vidaurre Arbizu, M.; Sancristan-Fernandez, J.A.; Martin-Gomez, C. Opaque Ventilated Façades: Thermal and energy performance review. Renew. Sustain. Energy Rev. 2017, 79, 180-191. [CrossRef]

12. Shameri, M.A.; Alghoul, M.A.; Sopian, K.; Zain, M.F.M.; Elayeb, O. Perspectives of double skin façade systems in buildings and energy saving. Renew. Sustain. Energy Rev. 2011, 15, 1468-1475. [CrossRef]

13. Quesada, G.; Rousse, D.; Dutil, Y.; Badache, M.; Hallé, S. A comprehensive review of solar facades. Opaque solar facades. Renew. Sustain. Energy Rev. 2012, 16, 2820-2832. [CrossRef]

14. Khanal, R.; Lei, C. Solar chimney-A passive strategy for natural ventilation. Energy Build. 2011, 43, 1811-1819. [CrossRef]

15. Saadatian, O.; Sopian, K.; Lim, C.H.; Asim, N.; Sulaiman, M.Y. Trombe walls: A review of opportunities and challenges in research and development. Renew. Sustain. Energy Rev. 2012, 16, 6340-6351. [CrossRef]

16. Alaidroos, A.; Krarti, M. Experimental validation of a numerical model for ventilated wall cavity with spray evaporative cooling systems for hot and dry climates. Energy Build. 2016, 131, 207-222. [CrossRef] 
17. Aleksandrowicz, O.; Yezioro, A. Mechanically ventilated double-skin facade in a hot and humid climate: Summer monitoring in an office tower in Tel Aviv. Archit. Sci. Rev. 2018, 61, 171-188. [CrossRef]

18. Wang, J.; Du, Q.; Zhang, C.; Xu, X. Energy Performance of Triple Glazed Window with Built-in Venetian Blinds by Utilizing Forced Ventilated airflow. Procedia Eng. 2017, 205, 3993-4000. [CrossRef]

19. Souza, L.C.; Souza, H.A.; Rodrigues, E.F. Experimental and numerical analysis of a naturally ventilated double-skin façade. Energy Build. 2018, 165, 328-339. [CrossRef]

20. Parra, J.; Guardo, A.; Egusquiza, E.; Alavedra, P. Thermal performance of ventilated double skin façades with venetian blinds. Energies 2015, 8, 4882-4898. [CrossRef]

21. Michaux, G.; Greffet, R.; Salagnac, P.; Ridoret, J.B. Modelling of an airflow window and numerical investigation of its thermal performances by comparison to conventional double and triple-glazed windows. Appl. Energy 2019, 242, 27-45. [CrossRef]

22. Gloriant, F.; Joulin, A.; Tittelein, P.; Lassue, S. Using heat flux sensors for a contribution to experimental analysis of heat transfers on a triple-glazed supply-air window. Energy 2021, 215, 119154. [CrossRef]

23. Asdrubaldi, F.; Baldinelli, G. Thermal transmittance measurements with the hot box method: Calibration, experimental procedures, and uncertainty analyses of three different approaches. Energy Build. 2011, 43, 1618-1626. [CrossRef]

24. Lucchi, E.; Roberti, F.; Alexandra, T. Definition of an experimental procedure with the hot box method for the thermal performance evaluation of inhomogeneous walls. Energy Build. 2018, 179, 99-111. [CrossRef]

25. Aviram, D.P.; Fried, A.N.; Roberts, J.J. Thermal properties of a variable cavity wall. Build. Environ. 2001, 36, 1057-1072. [CrossRef]

26. Andreotti, M.; Calzolari, M.; Davoli, P.; Pereira, L.D.; Lucchi, E.; Malaguti, R. Design and Construction of a New Metering Hot Box for the In Situ Hygrothermal Measurement in Dynamic Conditions of Historic Masonries. Energies 2020, 13, 2950. [CrossRef]

27. Sukamto, D.; Gloriant, F.; Siroux, M. Mise en place d 'un dispositif expérimental pour la caractérisation énergétique d'une paroi bioclimatique ventilée. In Proceedings of the Conférence SFT Belfort Therm. Mix Énergétique, Belfort, France, 1 June 2020.

28. Padet, J. Convection Thermique et Massique Principes Généraux; Techniques de l'ingenieur: Saint-Denis, France, $2005 ;$ pp. 1-23.

29. Fantuccia, S.; Serraa, V.; Perino, M. Dynamic insulation systems: Experimental analysis on a parietodynamic wall. Energy Procedia 2015, 78, 549-554. [CrossRef] 